\title{
Serum 1, 25-Hydroxyvitamin D: A Useful Index of Cognitive and Physical Functional Impairment in Healthy Older Adults in Japan: A Pilot Study
}

\author{
Noboru Hasegawa', Miyako Mochizuki², Mayumi Kato ${ }^{3}$, Takako Yamada ${ }^{4}$, Nobuko Shimizu${ }^{1}$, \\ Akihisa Torii ${ }^{3}$ \\ ${ }^{1}$ Department of Health and Medical Sciences, Ishikawa Prefectural Nursing University, Kahoku, Japan \\ ${ }^{2}$ Kyoto Bunkyo Junior College, Uji, Japan \\ ${ }^{3}$ Aichi Medical College for Physical and Occupational Therapy, Kiyosu, Japan \\ ${ }^{4}$ Bukkyo University, Kyoto, Japan \\ Email: hsgwn@ishikawa-nu.ac.jp
}

How to cite this paper: Hasegawa, N., Mochizuki, M., Kato, M., Yamada, T., Shimizu, N. and Torii, A. (2016) Serum 1, 25-Hydroxyvitamin D: A Useful Index of Cognitive and Physical Functional Impairment in Healthy Older Adults in Japan: A Pilot Study. Health, 8, 1679-1686. http://dx.doi.org/10.4236/health.2016.815163

Received: October 28, 2016

Accepted: December 3, 2016

Published: December 6, 2016

Copyright $\odot 2016$ by authors and Scientific Research Publishing Inc. This work is licensed under the Creative Commons Attribution International License (CC BY 4.0).

http://creativecommons.org/licenses/by/4.0/ (c) (i) Open Access

\begin{abstract}
We enrolled 23 Japanese men (age: $76.0 \pm 8.7$ ) and 17 women (age: $78.3 \pm 9.3$ ) in this study. The physical function of even a person getting on a wheelchair could be tested in all subjects. Blood was collected by venipuncture and the serum 1, 25-hydroxy vitamin D $(1,25 \mathrm{OHD})$ concentration was measured. The Mini-Mental State Examination (MMSE) and the Montreal Cognitive Assessment-Japanese version (MoCA-J) was used for the cognitive function test. Physical function was measured objectively using the Timed UP and Go (TUG) and 4-m walking test (4MWS). A significant positive correlation was found between serum 1, 25OHD and MMSE or MoCA-J. It is expected that an elderly person can maintain a mean serum 1,25OHD level of about $100 \mathrm{pg} / \mathrm{mL}$ for preventing early cognitive disorder. In the present study, a significant positive correlation was found between urinary 25 -hydroxy vitamin $\mathrm{D}$ (25OHD)/creatinine and MMSE or MoCA-J. Our results showed that urinary 25OHD might be a useful biomarker for predicting cognitive disorder. There was a significant negative correlation between serum 1, 25OHD and TUG or 4MWS. These findings suggest that serum 1,25OHD levels might serve as a useful index to improve cognitive and physical functional impairment.
\end{abstract}

\section{Keywords}

Serum 1, 25-Hydroxyvitamin D, Cognitive Function, Physical Function, Aging, Urinary 25-Hydroxyvitamin D 


\section{Introduction}

The proportion of older individuals in the population has been rapidly increasing in developed countries. In 2015, the average life expectancy of Japanese male and female was reportedly 80.5 and 86.8 years, respectively [1]. Japan has the highest proportion of older adults and so-called "Super-aged society" in the world. These results suggested that the prevalence of both cognitive and physical functional impairment increases with age. They experience difficulty in cognitive function, walking, housework and shopping in daily life. These are the main reasons for becoming bedridden or requiring nursing care.

Vitamin D is a secosteroid associated with peripheral calcium homeostasis [2]. Vitamin D is available in vitamin D2 of plants and D3 of animals. Both vitamin D2 and D3 are biologically inert and require activation through two hydroxylation processes involving 25 -hydrooxylase and $1 \alpha$-hydroxylase, located in the liver and kidney, respectively [3]. 1, 25-Dihydroxyvitamin D $(1,25 \mathrm{OHD})$ is a biologically active metabolite produced by two steps of hydroxylation reactions [4].

Recent evidence has identified a much broader physiological role for vitamin D including its neuroprotective effect [4]. The Mini-Mental State Examination (MMSE) was used for the cognitive function test developed by Folstein et al. in 1975 which is commonly used for dementia screening [5]. Vitamin D supplementation caused significant improvement in the cognitive performance by MMSE score in Alzheimer's disease [6]. The Montreal Cognitive Assessment (MoCA) may be better at detecting early cognitive dysfunction [7]. The low 25-hydroxy vitamin D (25OHD) level has been recently associated with greater risk of cognitive impairment in older as well as younger adults using the MoCA Arabic version [8]. These results suggested that serum vitamin $\mathrm{D}$ is the index of cognitive function. 1, 25OHD enters and acts on vitamin D target cells at the level of gene transcription [9]. Therefore, we focused on the serum 1, 25OHD levels.

Physical performance tests included balance, lower limbs muscular strength and walking speed. Vitamin D3 supplementation improves muscle function and physical performance in the elderly population using 4-meter walking test (4MWS) [10]. The Timed UP and Go (TUG) test of functional mobility is assessed by asking the participant to stand up from a standard chair, walk a 3 meter, turn, walk back to the chair and sit down again [11]. Lower serum $25 \mathrm{OHD}$ is associated with poorer functional mobility using walking speed, TUG, and cognitive function using MMSE [12]. However, the effectiveness of serum 1, 25OHD concentration on physical performance has not yet been tested.

Therefore, the present study was designed to investigate the effect of $1,25 \mathrm{OHD}$ in cognitive and physical functional impairment in healthy older adults in Japan. Our goal was to estimate the serum 1,25OHD cut-off value from the results of the cognitive tests (MMSE and MoCA) and physical performance measurement (4MWS and TUG test), and to predict the cognitive and physical function levels from the urine 25OHD concentration. 


\section{Methods}

\subsection{Subjects and Setting}

Prior to the study, approval was obtained from the ethics committee of Kyoto Bunkyo Junior College (project registration number in 2016: 7) and Aichi Medical College for Physical and Occupational Therapy (Project registration number in 2016: 468). A total of 40 healthy adults age $\geq 65$ years were included in adult day-care center clients in Kyoto $(n=16)$, Fukui $(n=8)$ and Aichi Prefectures $(n=16)$. These areas with varying daylight hours were selected. The annual daylight hours were maximum in Aichi (2255 hrs: the 4th in Japan), and minimum in Fukui (1788 hrs: the 37th in Japan) among the three areas. The researchers attended the adult day-care center and assured the proper management of safety and confidentiality of the study. The manager of the adult day-care center invited participation in the study, and all the subjects whose participation was requested selected from April to Jun in 2016. After obtaining informed consent from a family member belonging to the same household, we enrolled 23 Japanese men (age: $76.0 \pm 8.7$ ) and 17 women (age: $78.3 \pm 9.3$ ) in this study. The physical function of even a person getting on a wheelchair could be tested among all subjects.

\subsection{Cognitive Function Test}

MMSE was used for the cognitive function test. It consists of five downstream items of orientation, memory, attentiveness for calculations, speech function, and design capacity. The maximum score for the MMSE is 30 points, and individuals with a score of 24 points were recommended [5]. The Montreal Cognitive Assessment-Japanese version (MoCA-J) was used for the cognitive function test. These tests were performed by verbal questioning of 5- to 10-min duration by skilled occupational and physical therapists. The maximum score for the MoCA-J is 30 points, and individuals with a score of 26 points were the recommended [6].

\subsection{Physical Function}

Physical function was measured objectively using TUG and 4MWS tests performed by skilled physical therapists. The cut-off values for the predicting the level of risk of falls in community-dwelling elders are $13.5 \mathrm{sec}$ in TUG [13] and $1.0 \mathrm{~m} / \mathrm{sec}$ in 4MWS [14], respectively.

\subsection{Serum 1, 250HD and Urinary 250HD Assay}

Blood was collected by venipuncture and serum 1, 25OHD concentration was measured by Kyoto Biken Laboratories Inc. (Kyoto, Japan), Nikken Igaku Co. (Fukui, Japan) and Falco Holdings Co. (Kyoto, Japan). Urinary samples were centrifuged at $1500 \mathrm{rpm}$ for $10 \mathrm{~min}$ and stored at $-30^{\circ} \mathrm{C}$ for later analysis. On the day of assay, samples were thawed and 25OHD was assayed using an enzyme-linked immunosorbent assay kit (Immundiagnostik AG, USA). Creatinine was assayed using a commercial kit (Bioassay Systems, USA) and $25 \mathrm{OHD} /$ creatinine ratios were compared. 


\subsection{Statistics}

Relationships between MoCA-J, MMJSE, TUG, 4 MWT and serum 1, 25OHD or urinary $25 \mathrm{OHD} /$ creatinine were evaluated using Pearson's correlation coefficient. A p-value $<0.05$ was considered to be statistically significant. Analyses were carried out using SPSS 21 for Windows (IBM, Japan).

\section{Results}

\subsection{Study Subjects}

Characteristics of the study subjects are shown in Table 1. Mean age was 76.0 years for males $(n=23)$ and 78.3 years for females $(n=17)$. Obesity was defined as a body-mass index $(\mathrm{BMI}) \geq 25 \mathrm{Kg} / \mathrm{m}^{2}$. The prevalence of obesity defined from BMI was $26.1 \%$ in males and $41.2 \%$ in females.

\subsection{Serum 1, 250HD and Cognitive Function Relationship}

There was a significant positive correlation between serum 1, 25OHD and MMSE or MoCA-J. Pearson's correlation coefficient (2-tailed) of $0.360, t=2.31$, and $\mathrm{p}=0.026$ was obtained for MMSE and 0.448, $t=3.010$, and $\mathrm{p}=0.005$ for MoCA-J. The serum 1 , $25 \mathrm{OHD}$ cut-off value was $26.4 \mathrm{pg} / \mathrm{mL}$ for MMSE (24 points) and $97.6 \mathrm{pg} / \mathrm{mL}$ for MoCA-J (26 points) (Figure 1, Table 2). These results suggested that serum 1, 25OHD protects cognitive function.

Table 1. Characteristics of the study subjects.

\begin{tabular}{ccc}
\hline & Mean & S. D. \\
\hline Age $(\mathrm{y})$ & 77.0 & 9.0 \\
Body height $(\mathrm{cm})$ & 156.8 & 8.2 \\
Body weight $(\mathrm{Kg})$ & 59.7 & 10.3 \\
BMI $\left(\mathrm{Kg} / \mathrm{m}^{2}\right)$ & 24.3 & 3.8 \\
\hline
\end{tabular}
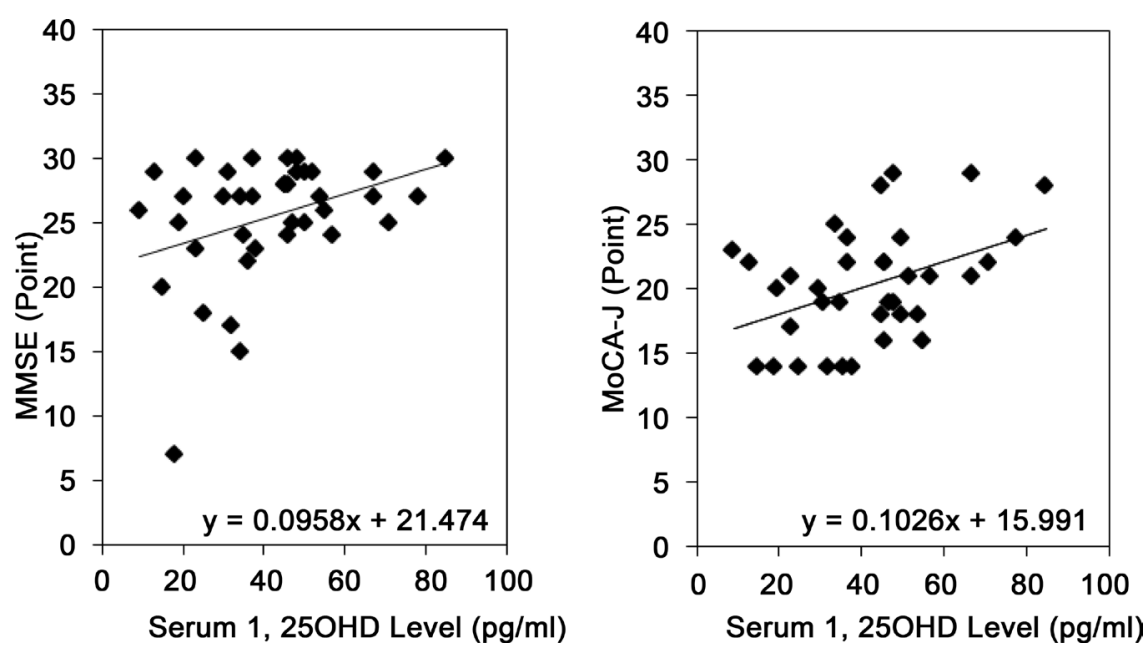

Figure 1. Effects of serum 1, 25OHD on cognitive function. 
Table 2. The level of the serum 1,25OHD and urinary 25OHD cut-off values for cognitive function.

\begin{tabular}{ccc}
\hline & \multicolumn{2}{c}{ Cognitive Function } \\
\cline { 2 - 3 } & MMSE & MoCA-J \\
\hline Serum 1, 25OHD $(\mathrm{pg} / \mathrm{mL})$ & 26.4 & 97.6 \\
$\log ($ Urinary $25 \mathrm{OHD} / \mathrm{creatinine})$ & 2.6 & 4.9 \\
\hline
\end{tabular}
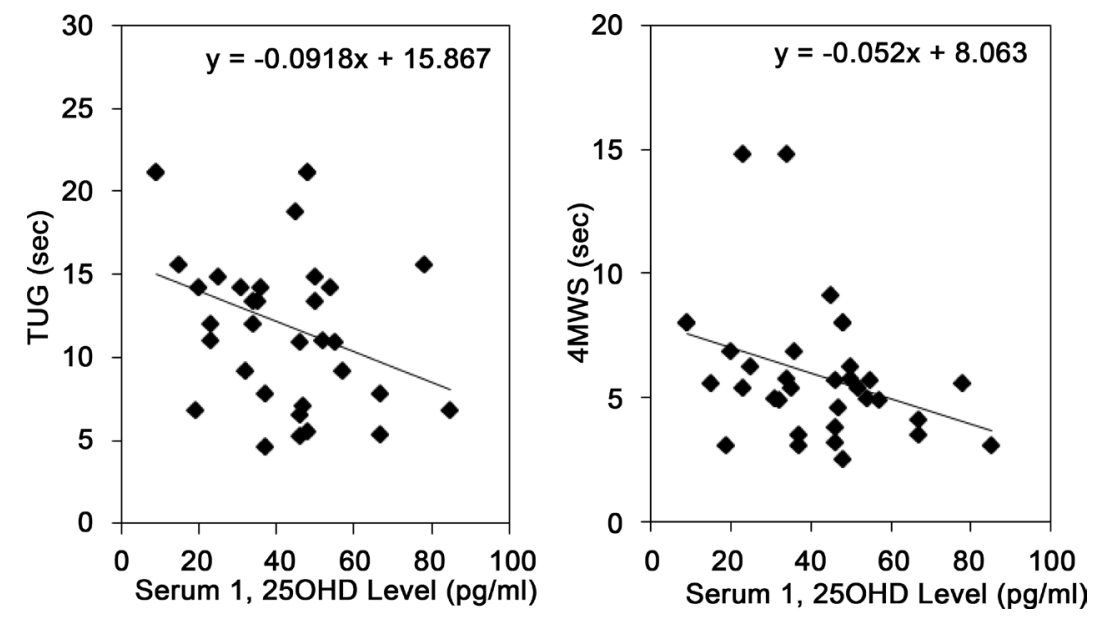

Figure 2. Effects of serum 1, 25OHD on physical function.

Table 3. The level of the serum 1, 25OHD cut-off values for physical functions.

\begin{tabular}{lcc}
\hline & TUG & 4MWS \\
\hline Serum 1, 25OHD $(\mathrm{pg} / \mathrm{mL})$ & 25.8 & 78.1 \\
\hline
\end{tabular}

\subsection{Serum 1, 250HD and Physical Function Relationship}

There was a significant negative correlation between serum 1, 25OHD and TUG or 4MWS. Pearson's correlation coefficient (2-tailed) of $-0.338, t=2.031$, and $\mathrm{p}=0.050$ was obtained for TUG and $-0.336, t=2.022$, and $\mathrm{p}=0.050$ for 4 MWS. Serum 1 , 25OHD cut-off value was $25.8 \mathrm{pg} / \mathrm{mL}$ for TUG $(13.5 \mathrm{sec}$ ) and $78.1 \mathrm{pg} / \mathrm{mL}$ for $4 \mathrm{MWS}$ (4 sec) (Figure 2, Table 3). These findings suggest that serum 1, 25OHD levels could contribute to improve physical function.

\subsection{Urinary 250HD and Cognitive Function Relationship}

There was a significant positive correlation between urinary Log $(25 \mathrm{OHD} /$ creatinine) and MMSE or MoCA-J. Pearson's correlation coefficient (2-tailed) of $0.400, t=2.62$, and $\mathrm{p}=0.012$ was obtained for MMSE and $0.405, t=2.657$, and $\mathrm{p}=0.012$ for MoCA-J (Figure 3, Table 2). These findings suggest that urinary 25OHD might be a useful biomarker for predicting cognitive disorder.

\section{Discussion}

In the present study, there was a significant positive correlation between serum 1,25 

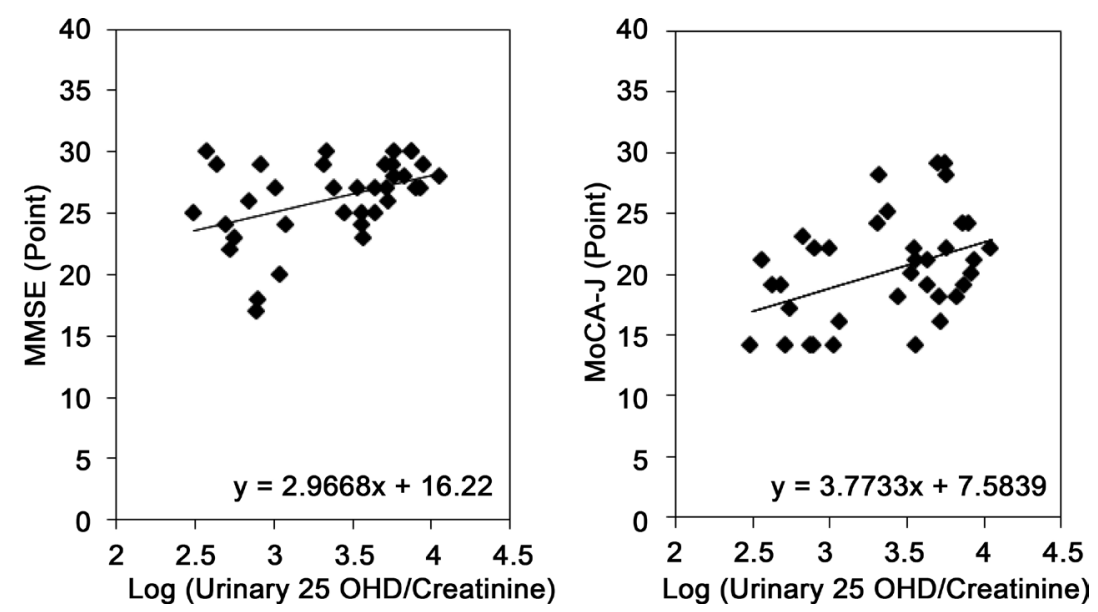

Figure 3. Effects of urinary $25 \mathrm{OHD}$ on cognitive function.

OHD and MMSE or MoCA-J. The MoCA may be a more challenging test for cognitively intact individuals. The total scores on the MoCA were lower than those on the MMSE [15]. In our results, the cut-off value of 1, 25OHD in MoCA-J was about ten-fold higher than that in MMSE. 1, 25OHD plays a neuroprotective role in human brain pericytes in culture [16]. Serum 25OHD was positively associated with cognitive performance [7] [8]. The circulating 1, 25OHD is produced from 25OHD in the kidney [4]. These results suggested that serum $1,25 \mathrm{OHD}$ protects cognitive function. It is expected that an elderly person maintains a mean serum 1, 25OHD level of about 100 $\mathrm{pg} / \mathrm{mL}$ for preventing early cognitive disorder. This level is higher than the normal circulation level $(10-80 \mathrm{pg} / \mathrm{mL})$ [9]. One must be careful about balanced diets and nutrition as well as excess avoidance of ultraviolet light.

The present study demonstrated a significant positive correlation between urinary $25 \mathrm{OHD} /$ creatinine and MMSE or MoCA-J. To our knowledge, ours is the first study to examine the effect of urinary $25 \mathrm{OHD}$ on cognitive function. Urine collection is noninvasive and readily available. In conclusion, our results show that urinary $25 \mathrm{OHD}$ might be a useful biomarker for predicting cognitive disorder.

The serum 25OHD concentration is known to contribute to physical performance [10] [12]. Our results suggested that there was a significant negative correlation between serum 1, 25OHD and TUG or 4MWS. These findings suggest that serum 1, 25OHD levels could contribute to improving physical function. Japan has the world's highest proportion of older adults. Locomotive syndrome means being restricted in one's ability to walk or lead a normal life owing to dysfunction in one or more of the parts including muscles [17]. These findings show that rehabilitation associated with serum 1, 25OHD as an index may be beneficial.

Over expression of reactive oxygen species (ROS) stimulated by the disruption of cerebral blood flow is one of the main causes of vascular dementia-induced cognitive deficits and behavioral dysfunction in the rat model [18]. Skeletal muscle mitochondrial function declines and oxidative stress increases with advancing age [19], and these changes have been implicated in the etiology of sarcopenia [20]. 1, 25OHD was re- 
ported to have a significant physiological antioxidant activity [21]. Thus 1, 25OHD passively acts by activation of the antioxidant pathway. In conclusion, antioxidant 1 , $25 \mathrm{OHD}$ may be recommended as a supplement to maintain cognitive and physical function.

The limitation of this study includes small sample size and possible selection bias. Further subjects are needed.

\section{Acknowledgements}

This work was supported by JSPS KAKENHI Grant Number JP22500682.

\section{References}

[1] Japanese Orthopedic Association (2010) Guidebook on Locomotive Syndrome. Bunkodo, Tokyo. (In Japanese)

[2] DeLuca, G.C., Kimball, S.M., Kolasinski, J., Ramagopalan, S.V. and Ebers, G.C. (2013) The Role of Vitamin D in Nervous System Health and Disease. Neuropathology and Applied Neurobiology, 39, 458-484. https://doi.org/10.1111/nan.12020

[3] Holick, M.F. (2007) Vitamin D Deficiency. New England Journal of Medicine, 357, 266-281. https://doi.org/10.1056/NEJMra070553

[4] Garcion, E., Wion-Barbot, N., Montero-Menei, C.N., Berger, F. and Wion, D. (2002) New Clues about Vitamin D Functions in the Nervous System. Trends in Endocrinology \& Metabolism, 13, 100-105. https://doi.org/10.1016/S1043-2760(01)00547-1

[5] Folstein, M.F., Folstein, S.E. and McHugh, P.R. (1975) “Mini-Mental State". A Practical Method for Grading the Cognitive State of Patients for the Clinician. Journal of Psychiatric Research, 12, 189-198. https://doi.org/10.1016/0022-3956(75)90026-6

[6] Gangwar, A.K., Rawat, A., Tiwari, S., Tiwari, S.C., Narayan, J. and Tiwari, S. (2015) Role of Vitamin-D in the Prevention and Treatment of Alzheimer's Disease. Indian Journal of Physiology and Pharmacology, 59, 94-99.

[7] Nasredding, Z.S., Phillips, N.A., Bédirian, V., Charbonneau, S., Whitehead, V., Collin, I., Cummings, J.L. and Chertkow, H. (2005) The Montreal Cognitive Assessment, MoCA: A Brief Screening Tool for Mild Cognitive Impairment. Journal of the American Geriatrics Society, 53, 695-699. https://doi.org/10.1111/j.1532-5415.2005.53221.x

[8] Darwish, H., Zeinoun, P., Ghusn, H., Khoury, B., Tamim, H. and Khoury, S.J. (2015) Serum 25-Hydroxyvitamin D Predicts Cognitive Performance in Adults. Neuropsychiatr. Dis. Treat., 11, 2217-2223.

[9] Jones, G. (2008) Pharmacokinetics of Vitamin D Toxicity. The American Journal of Clinical Nutrition, 88, 582s-586s.

[10] Lagari, V., Gómez-Marín, O. and Levis, S. (2013) The Role of Vitamin D in Improving Physical Performance in the Elderly. Journal of Bone and Mineral Research, 28, 2194-2201. https://doi.org/10.1002/jbmr.1949

[11] Podsiadlo, D. and Richardson, S. (1991) The Timed "UP \& Go": A Test of Basic Functional Mobility for Frail Elderly Persons. Journal of the American Geriatrics Society, 39, 142-148. https://doi.org/10.1111/j.1532-5415.1991.tb01616.x

[12] Gschwind, Y.J., Bischoff-Ferrari, H.A., Bridenbaugh, S.A., Härdi, I. and Kressig, R.W. (2014) Association between Serum Vitamin D Status and Functional Mobility in Memory Clinic Patient Aged 65 Years and Older. Gerontology, 60, 123-129. 
http://dx.doi.org/10.1159/000355667

[13] Shumway-Cook, A., Brauer, S. and Woollacott, M. (2000) Predicting the Probability for Falls in Community-Dwelling Older Adults Using the Timed Up \& Go Test. Physical Therapy, 80, 896-903.

[14] Quach, L., Galica, A.M., Jones, R.N., Procter-Gray, E., Manor, B., Hannan, MT., et al. (2011) The Nonlinear Relationship between Gait Speed and Falls: The Maintenance of Balance, Independent Living, Intellect and Zest in the Elderly of Boston Study. Journal of the American Geriatrics Society, 59, 1069-1073. http://dx.doi.org/10.1111/j.1532-5415.2011.03408.x

[15] Gluhm, S., Goldstein, J., Loc, K., Colt, A., Liew, C.V. and Corey-Bloom, J. (2013) Cognitive Performance on the Mini-Mental State Examination and the Montreal Cognitive Assessment across the Healthy Adult Lifespan. Cognitive \& Behavioral Neurology, 26, 1-5. http://dx.doi.org/10.1097/WNN.0b013e31828b7d26

[16] Nissou, M.F., Guttin, A., Zenga, C., Berger, F., Issartel, J.P. and Wion, D. (2014) Additional Clues for a Protective Role on Vitamin D in Neurodegenerative Diseases: 1, 25-Dihydroxyvitamin D3 Triggers an Anti-Inflammatory Response in Brain Pericytes. Journal of Alzheimer's Disease, 42, 789-799. http://dx.doi.org/10.3233/JAD-140411

[17] Japanese Orthopedic Association (2013) Locomotive Syndrome Pamphlet.

[18] Li, Z., Wang, Y., Xie, Y., Yang, Z. and Zhang, T. (2011) Protective Effects of Exogenous Hydrogen Sulfide on Neurons of Hippocampus in a Rat Model of Brain Ischemia. Neurochemical Research, 36, 1840-1849. http://dx.doi.org/10.1007/s11064-011-0502-6

[19] Petersen, K.F., Morino, K., Alves, T.C., Kibbey, R.G., Dufour, S., Sono, S., et al. (2015) Effect of Aging on Muscle Mitochondrial Substrate Utilization in Humans. Proceedings of the National Academy of Sciences of the United States of America, 112, 11330-11334. http://dx.doi.org/10.1073/pnas.1514844112

[20] Joseph, A.M., Adhihetty, P.J. and Leeuwenburgh, C. (2016) Beneficial Effects of Exercise on Age-Related Mitochondrial Dysfunction and Oxidative Stress in Skeletal Muscle. The Journal of Physiology, 594, 5105-5123. http://dx.doi.org/10.1113/JP270659

[21] Calgaroto, N.S., Thomé, G.R., da Costa, P., Baldissareli, J., Hussein, F.A., Schmats, R., et al. (2014) Effect of Vitamin $D_{3}$ on Behavioral and Biochemical Parameters in Diabetes Type 1-Induced Rats. Cell Biochemistry and Function, 32, 502-510. http://dx.doi.org/10.1002/cbf.3044 
Submit or recommend next manuscript to SCIRP and we will provide best service for you:

Accepting pre-submission inquiries through Email, Facebook, LinkedIn, Twitter, etc.

A wide selection of journals (inclusive of 9 subjects, more than 200 journals)

Providing 24-hour high-quality service

User-friendly online submission system

Fair and swift peer-review system

Efficient typesetting and proofreading procedure

Display of the result of downloads and visits, as well as the number of cited articles

Maximum dissemination of your research work

Submit your manuscript at: http://papersubmission.scirp.org/

Or contact health@scirp.org 